\title{
ЛЕКСИКОГРАФСКА ОБРАДА НАЗИВА ЗА БОЛЕСТИ, СИМПТОМЕ И ЗНАКЕ У ДЕЛУ ЧАДОљУБ ИЛИ НЕГОВАЪЕ ДЕЦЕ У ПРВИМ ЖИВОТА ГОДИНАМА ГАВРИЛА ПЕКАРОВИЋА (1836) ${ }^{1}$
}

\begin{abstract}
САЖЕТАК
У раду се даје предлог за лексикографску обраду назива за болести, симптоме и знаке забележене у делу Чадољуб или неговање деце у првим живота годинама Гаврила Пекаровића, из 1836. године. Поред речника, дате су опште информације о медицини као научној дисциплини код Срба и урађено је поређење са савременим медицинским речницима: Вишејезички медицински речник и Медицински лексикон.
\end{abstract}

КљУЧНЕ РЕЧИ: називи болести, симптоми, знаци, терминологија, медицина, 19. век.

\section{1. Медицина као научна дисциплина код Срба}

Иако се човек, сасвим је извесно, лечењем бави одвајкада, медицина (у научном смислу) родила се код Срба у време српске средњовековне државе и њен почетак блиско је повезан с друштвено-политичким и економским стањем у коме се тада налазила наша држава. У то време осећао се јак утицај Византије и Запада, а с обзиром на то да је Византија културно, политички и верски утицала на словенско становништво, српска медицина је била у уској вези с манастирима где су се углавном преводили и преписивали антички списи из школе Галена, Хипократа, Аристотела и др.

\footnotetext{
${ }^{1}$ Чланак је настао као резултат истраживања и писања мастерског рада Називи за болести, симптоме и знаке у делу „Чадољуб или неговање деце у првим живота годинама" Гаврила Пекаровића (1836), под менторством проф. др Исидоре Бјелаковић.
} 
(Станојевић 1953: 1028; Катић 1971: 11, Бјелаковић 2004: 5). Прве болнице отворене су управо при манастирима Хиландару (око 1191. г.) и Студеници (1208), а отворио их је Свети Сава. Византијски утицај је био најјачи пред крај 13. века након Милутинових освајања византијских области у Повардарју. У препису Шестоднева Јована Егзарха ${ }^{2}$ нашли су се битни делови из биологије и физиологије (Катић 1971: 13). Што се тиче западњачког утицаја, долазио је из Италије ${ }^{3}$ преко Котора, јер је српска средњовековна држава одржавала одличне културне и трговачке везе с Италијом. Да је постојао западњачки утицај, говори нам и то да се у Хиландарском медицинском кодексу налази 12 списа и архивских докумената из старог Котора. Веома битно је истаћи да је српска медицина у средњем веку имала изграђену медицинску терминологију о чему нам сведочи неколико сачуваних споменика међу којима је свакако најзначајнији Хиландарски медицински кодекс ${ }^{4}$ (Катић 1971: 57). Све до 15. века, српска медицина константно расте и развија се, али њен раст бива прекинут пропашћу српске средњовековне државе и доласком Турака на Балкан када почиње њена регресија и такво стање ће бити до друге половине 18. века, тачније до 1757, када ће се појавити први лекар доктор медицине, Јован Апостоловић. С њиме ће средњовековна медицина престати и почеће савремена европска (Катић 1971: 11; 1971: 64). Након појаве Јована Апостоловића, у другој половини 18. века, у Војводини су постојала 3 школована лекара, а у првој половини 19. века чак 31. Тада почиње и да излази медицинска књижевност по доктору А. С. Шевићу све до 1836. г. (Станојевић 1953: 1031). Једно од дела које је изашло у тој „едицији”, било је и дело Чадољуб или неговање деце у првим живота годинама 1836. Гаврила Пекаровића. С појавом првих лекара почињу да ничу и прве болнице - у Новом Саду отворена је 1730, у Вршцу 1779, у Сремским Карловцима 1779.

\footnotetext{
${ }^{2}$ Преписао га је Теодор Граматик 1236. по налогу Доментијана.

${ }^{3}$ У граду Салермо налазила се чувена медицинска школа.

${ }^{4}$ Хиландарски медицински кодекс је најзначајнији медицински споменик, пронађен у библиотеци манастира Хиландар. Пронашао га је 1952. Ђорђе Сп. Радојичић. Има 204 листа, написан је српском рецензијом и потиче с краја 15. или почетка 16. века. Овај спис је доказ да утицај западноевропске медицине није био само ограничен на земље којима је италијанска култура била доминантна, јер се у овом споменику налазе списи салеренско-монпељеске школе који нису били написани на латинском језику (Катић 1971: 33).
} 
године (Бјелаковић 2004: 8). Први санитет обновљене Србије (Србије за време кнеза Милоша Обреновића) основан је због тога што је он желео да школовани лекари који су завршили медицину на европским универзитетима дођу у Србију. Они су углавном долазили у личну службу кнеза и његове породице. Пред крај прве Милошеве владавине у Србији је било 9 лекара (Драгић 1971: 173). На крају 19. века почело је оснивање Друштва за чување народног здравља, које је 1902. године почело с радом и за чијег је председника изабран др Милан Јовановић Батут. Ово друштво је имало за циљ да се народ здравствено просвећује тако што ће се отворити разни курсеви за сеоске домаћице (Драгић 1971: 178). Медицина, као наука и као култура, започета је још 1838. у крагујевачком Лицеју, да би 1841. Лицеј био пресељен у Београд, 1853. унапређен, 1863. претворен у Велику школу, 1905. у Универзитет, коме је 1919. додат Медицински факултет у Београду (Станојевић 1953: 1053).

\section{2. Предмет, корпус и циљ истраживања}

Предмет овог рада је лексикографска обрада назива за болести, симптоме и знаке који су били заступљени у предстандардној епоси српског језика. Корпус за анализу представљало је дело Гаврила Пекаровића ${ }^{5}$ Чадољуб или неговање деце у првим живота годинама (1836). Овај лекар је рођен 1811. ${ }^{6}$ у Оросламошу ${ }^{7}$ надомак Кикинде. О њему се мало зна у литератури о историји медицине, а и уопште. Написавши своју докторску дисертацију Disertatio inaguralis medica de salitina, завршава студије медицине у Пешти 1836. и добија титулу доктора медицине. Чадољуб или неговање деще у првим живота годинама 8 прва је књига о неговању деце код нас. Г. Пекаровић ју је написао још као студент, али је објављена 1836. године у Будиму, док је предговор написан у Пешти 1. фебруара исте године. Књига је посвећена „Високоблагородној госпои Анастасији Нако от Великог Сент-Миклош рођ. Вучетић“. Чадољуб није оригинално дело - као главни узор за ову књигу Пекаровићу је послужила Хуфландова (немачки хигијеничар) књига из

\footnotetext{
${ }^{5}$ Биографија и остале информације о животу Гаврила Пекаровића су преузете од: Токин (1953) и Павловић-Велисављев (1995).

${ }^{6}$ Павловић и Велисављев наводе да је година рођења Г. Пекаровића 1812.

${ }^{7}$ Банатско Аранђелово.

${ }^{8}$ У наставку ће се користити само Чадољуб.
} 
1799. ${ }^{9}$ Чадољуб је сматран допуном Пејчићеве књиге Руководитељ к свеопштему здрављу (1830) и представља упутства за неговање мале деце како би се сачувала од многобројних болести, телесних мана и смртности. Књига је малог формата, на свега 104 странице, садржи 46 поглавља и писана је предвуковском ћирилицом. Тек 1979. године је умножена на 3000 примерака, а до тада су постојала само два. Најлепше године свог живота овај лекар је провео у Вршцу у који је дошао 1836. године, где је радио као лекар Српског опшчества и као управник Српског шпитаља и у ком је упознао Јована Стерију Поповића коме је био лични лекар и пријатељ. О дубини њиховог пријатељства сведоче чињенице да је Стерија Г. Пекаровићу посветио Тврдииу ${ }^{10}$ и да су на вршачком гробљу сахрањени један поред другог по сопственој жељи. Гаврил Пекаровић је умро 8. марта 1851, али се његови савети из Чадољуба и данас примењују, те се он може сматрати зачетником српске и јужнословенске педијатрије (в. Токин 1953; ПавловићВелисављев 1995). Мотиви за избор медицинске терминологије за тему овог рада били су жеља да се прикупи лексичка грађа и састави речник медицинских назива с обзиром на то да је здравље битан сегмент човековог живота од његовог рођења, необично интересовање за медицину, али и будуће мајчинство. Основни задатак овог истраживања је издвајање термина $^{11}$ у виду речника. Ексцерпирана грађа дата је у виду речника с дефиницијом и потврдом оригинала.

\footnotetext{
9 Dr. Christ. Wilh. Hufeland's Guter Rath an Mütter über die physische Erziehung der Kinder.

${ }^{10}$ Видети посвету у Тврдищи .

11 Термини су речи које представљају називе за појмове у одређеним научним областима (научна, техничка, уметничка) и њихов језички знак се поклапа са одговарајућим појмом у појмовном систему дате научне области (Гортан-Премк 1988: 15; Драгићевић 2007: 20; Бјелаковић 2017: 18; Macanović 2018: 11). Установљено је и шта термин све треба да „поседује“ да би био идеалан, тј. да би се разликовао од општег лексичког фонда: 1) транспарентност (прозирност значења), 2) интернационалност, 3) устаљеност (да буде прихваћен), 4) краткоћа (монолексемски), 5) системност (да буде у систему), 6) недвосмисленост, 7) прецизност, 8) несинонимност, 9) одсуство експресивности и стилска неутралност, 10) слаба метафоризација (Šipka 1998: 128).
} 


\section{3. Лексикографска обрада}

С обзиром на то да је овај речник намењен широј читалачкој публици, а не само лингвистима, грађа у речнику је транскрибована и уазбучена према савременој азбуци српског језика (Кашић 1984: 94) како би се на овај начин олакшало читање овог дела управо онима који нису лингвисти и омогућило да створе општу и ширу слику о медицинској терминологији 19. века (Бјелаковић 2017: 198). Транскрипција је рађена према упутствима Александра Младеновића (1979). Уз многе одреднице дат је и систем забележених вишечланих јединица - под Изр. Структура речничког чланка у овом раду подразумева следеће елементе: 1. одредницу (транскрибовану једночлану или вишечлану терминолошку јединицу) маркирану болдом, 2 . граматичку информацију: уз именице: обележје рода (м, с, ж), уз придеве: наставци који носе обележје рода (-a, -о), уз глаголе: обележје вида (сврш. и несврш.), 3. регистровану форму у оригиналу (дату у угластим ортографским заградама), 4. дефиницију (у курзиву) ако је пронађена у изворима, а ако није, употребљен је симбол (?), 5. потврду са ширим контекстом у којем је пример забележен с иницијалима, називом дела у виду скраћенице, годином и страном на којој је пример забележен, 6. изразе (Изр.) (в. Бјелаковић 2013; Бјелаковић и Цветковић-Теофиловић 2017). Приликом дефинисања коришћени су следећи речници: Речник српскохрватског књижевног језика I-VI, Етимологијски рјечник хрватскога или српскога језика, Речник српскохрватског книжевног и народног језика I-XIV, као и Грађа за медииинску терминологију. Уколико би се приликом навођења контекста испустио део који није релевантан за потврђивање дате одреднице, он би се означавао угластом заградом и трима тачкама: [...]. Приликом давања дефиниција код Изр., оне нису даване код устаљених спојева прозирног значења (нпр. бол прсију). С друге стране, редовно су дефинисани вишечлани спојеви непрозирне семантике (нпр. велика болест). У речнику се налазе и поједине речи и изрази који на први поглед могу изазвати недоумице у вези с оправданошћу смештања у речник (нпр. бува, мртвом подобно лежати), а критеријуми за то су свакако били патологија и симптоматологија, нпр. ујед буве на човековој кожи изазива свраб и осип, али исто тако, у зависности ког је домаћина бува пре имала, може пренети кугу, мишји тифус, док је псећа бува посредан домаћин пантљичаре; а израз мртвом подобно лежати 
представља стање „одложене смрти” и губитак животних функција, услед губитка услова за правилан рад мозга, односно кому.

\section{4. Речник}

Б

БАЛА ж <бала*> слуз из уста и носа; слина. - Што се пакъ положенія детета при спаваню тиче, никадъ неваля на леђа, но садъ на едной садъ на другой страни да лежи, еръ ако на лећи узлежи, бале ћеду му се изъ носа у уста и грло слити, кое га лако угнявити могу (ГП Ч 1836: 70).

\section{БЕЗВРЕМЕНИ РОЂАЈ}

<безвременый рођай> порођај који не пада у одговарајуће време, неблаговремен, преурањен. - Девойчице, кое се измалена іоштъ на нъга навикну, носе га понайвыше и онда іоштъ, кадъ се већъ удаду, и трудне постану; онда пакъ управъ убиточно естъ, еръ разширеніе материце и изображеніе детета препятствуюћи прераный, или безвременый рођай узрокуе (ГП - Ч 1836: 66).

БЕЛО ПРАҢЕ с <бело пранъ > појачан секрет код жена, бели вагинални исиедак. - Горко се вараю оне, кое мысле да доень здравль и лепоту матере нарушава; шта выше, жалостни примьри иляадама сведоче, да башъ оне, кое свету дужностъ ову пренебрегаваю, найгадніимъ и найопасніимъ болестима подложне есу, лютый болъ, жестоко запаленіе, ране, чворови, ракъ сиса; запаленіе, отврдненіе, ракъ материце; бело пранђ, гадне красте, ране и проч: ову су за оне, кое безъ свакогъ довольногъ узрока свету доеня дужностъ пренебрегаваю, оть правдолюбиве природе опредълене награде [...] (ГП - Ч 1836: 13).

БЛЕДИТИ несврш. <бледити> остајати без природног руменила, без животне боје. - Но и овде има изяатія; ако е сирьчъ Мати, или дойкиня врло слаба, иль мало млека имаде, дете напротивъ яко и при добромъ апетиту, ако оне при доеню болъ прсию сувостъ уста и грла, зуянъ ушію осећаю; а дете поредъ овы безъ свакогъ узрока неспокойно спавати, бледити, мршавити почне, то е, макаръ се првогъ живота месеца збыло, знакъ да дете са самомъ сисомъ задовольно ніе, зато му поредъ ове и друга ела давати почети валя (ГП Ч 1836: 51).

БОЛ м <боль> непријатан осећај телесне, физичке патюе због повреде или болести, поремећаја у организму. Горко се вараю оне, кое мысле да доень здравль и лепоту матере нарушава; шта выше, жалостни примьри иляадама сведоче, да башъ оне, кое свету дужность ову пренебрегаваю, найгадніимъ и найопасніимъ болестима подложне есу, лютый болъ, жестоко запаленіе, ране, чворови, ракъ сиса; 
запаленіе, отврдненіе, ракъ материце [...] (ГП - Ч 1836: 13).

Изр. бол прсију м <болъ прсію> Овако дете стомахъ обтеретити неће, а матиће избегнути многа коекаква зла, као: боль прсію, протисли, сувость уста, кашаль и проч. коя бы ю, кадъ ова наблюдавала небы, врло лако мучити могла (ГП - Ч 1836: 21).

БОЛЕСТ ж <болесть*> нездраво стане организма изазвано поремећајем юегових животних функиија; обољење. - Горко се вараю оне, кое мысле да доенъ здравль и лепоту матере нарушава; шта выше, жалостни примьри иляадама сведоче, да башъ оне, кое свету дужность ову пренебрегаваю, найгадніимъ и найопасніимъ болестима подложне есу, лютый боль, жестоко запаленіе, ране, чворови, ракъ сиса; запаленіе, отврдненіе, ракъ материце; бело прань, гадне красте, ране и проч: ову су за оне, кое безъ свакогъ довольногъ узрока свету деня дужностъ пренебрегаваю, оть правдолюбиве природе опредълене награде; гди на противъ оне, кое природнымъ законима задоста чине и плодъ свой съ собственомъ сисом дое, одъ речены, заиста гадны и опасны болести, врло редко што знаду (ГП - Ч 1836: 13).

Изр. велика болест ж <велика болесть*> lat. epilepsia (Батут) болест која се исповљава повременим нападима губитка свести с грчевима и трзајима читавог тела; падавица. - Налази се и тако несрећны матера, кое макаръ да можностъ доеня притяжаваю, опеть дужностъ ову извршавати несмеду; еръ бы чрезъ ню како себи, тако и невиномъ дедету свомъ шкодити могле. Овамо принадлеже: [...] 6. Кое наклоностъ къ шкрофулама, хектики, великой болести и т.д. имаду; особито ако е насльдствена (ГП - Ч 1836: 28).

внутрења болест ж <внутреня болесть*> болест унутрашњих органа. - Но съ овимъ задовольити се нетреба, но за увЂритисе о здравлю нђном, валя іой цело тъло, отъ главе до ногу визитирати и добро прогледати, да неима гдигодъ какве красте, да іой коса ніе сльплЂна, да іой нетеку носъ или уши, да ніе ункава, да неима у усты, носу ил' у грлу приштъ, да некашль, да іой неудараю уста, ил' ноге, да іой нису сисе ил' тайне части болестне, да неима бело пранъ, раняве ил' отечене ноге, ил' руке, внутреню какву болестъ и проч (ГП - Ч 1836: 31).

водена болест ж <водена болесть*> lat. hydrops (Батут) нагомилавање течности око зглобова и у трбушној дупљи. - [...] нити е мало число жена, кое су само збогъ пренебрегнутогъ доеня хектику, водену болестъ, свакояке душевне болести и проч: на себе навукле (ГП - Ч 1836: 14).

водена болест главе ж < водена болесть главе*> lat. hydrocephalus. водена глава, хидроцефалус. - Но ако башъ то и ніе, опеть сироте мале туђегъ млека зла сльдства необилазе: разрану имъ се уста, поквари стомахъ, добію повраћиванъ, цревопролитіе, водену болесть главе, и понайвыше, падши у 
суву болестъ, на брзо жалостный животъ свой окончаваю (ГП - Ч 1836: 16).

грудна болест ж <грудна болесть*> болести грудног коша и органа у њему, грудобоља, туберколоза. - Деца се яко усиляваю, ноге имъ се, немогући цело тело држати, криве, тако исто и кичменица, речена орудія кваре прси, наклоность къ грудным болестима узрокую и т.Д. (ГП - Ч 1836: 75).

душевна болест ж <душевна болесть*> психичко, ментално обољене. - И сама страшна она породильна грозница, коя породиль илядама у въчность преселява, по многи славны лекара мнънію, одъ разудареног по тьлу млека произылази, и понайвыше на оне, кое недою, напада; нити е мало число жена, кое су само збогъ пренебрегнутогъ доеня хектику, водену болесть, свакояке душевне болести и проч: на себе навукле (ГП - Ч 1836: 14).

навући болест сврш. <навући болесть*> оболети, разболети се. - Ова може чрезъ преправлянь силнога млека ослабити и свакояке болести на себе навући; оно пакъ чрезъ много ело желудацъ покварити, повраћиванъ, цревопролитіе, грижу, и друга зла добити може (ГП - Ч 1836: 19).

наследствена болест ж <насльдствена болесть*> она која се преноси као карактеристика, особина, стање и сл. од предака на потомке, наследна болест. - Налази се и тако несрећны матера, кое макаръ да можностъ доеня притяжаваю, опеть дужность ову извршавати несмеду; еръ бы чрезъ ню како себи, тако и невиномъ дедету свомъ шкодити могле. Овако принадлеже: 1. Отвећъ младе и старе. 2. Кое врло слабъ тъла составъ имаду; кое оть грчева много страдаю. (27) 3. Кое болестне сисе, као краставе, раняве, чворновите и проч: имаду. 4. Кое рђаво млеко имаду. 5. Кое крвъ плюю или блюю. 6. Кое наклоность къ шкрофулама, хектики, великой болести и т.д. имаду; особито ако е насльдствена. 7. Кое прильпчиве болести, венерію, шугу, и проче друге имаду. 8. Кое материцу болестну имаду. 9. Кое отъ душевне какве болести страдаю (ГП - Ч 1836: 28).

прилепчива болест м <прильпчиве болесть*> заразна болест - Налази се и тако несрећны матера, кое макаръ да можность доеня притяжаваю, опетъ дужность ову извршавати несмеду; еръ бы чрезъ ню како себи, тако и невиномъ дедету свомъ шкодити могле. Овамо принадлеже: 1. Отвећъ младе и старе. 2. Кое врло слабъ тьла составъ имаду; кое оть грчева много страдаю. 3. Кое болестне сисе, као краставе, раняве, чворновите и проч: имаду. 4. Кое рђаво млеко имаду. 5. Кое крвъ плюю или блюю. 6. Кое наклоность къ шкрофулама, хектики, великой болести и т.д. имаду; особито ако е насльдствена. 7. Кое прильпчиве болести, венерію, шугу, и проче друге имаду. 8. Кое материцу болестну имаду. 9. Кое отъ душевне какве болести страдаю (ГП - Ч 1836: 28). 
сува болест ж <сува болесть*> грудна болест, туберколоза. -Тврда и врло густа ела узрокую грижу, цревопролитіе, наклоность къ гукама (шкрофулама), добрацу (rhachitis), сувой болести, много пута и саму напрасну смрть (ГП - Ч 1836: 51).

БОЛЕСТАН, -сна, -сно који је захваћен болешћу.

Изр. болесна глава ж <болестна глава*> - Уваћена већъ кора извидати се може сльдуюћимъ начиномъ: намазати валя болестну главу съ неосольном масћу, мало после добро е опрати валя са сапунскомъ водом [...] (ГП - Ч 1836 : 88).

болесна материца ж <болестна материца*> - Налази се и тако несрећны матера, кое макаръ да можность доеня притяжаваю, опеть дужность ову извршавати несмеду; еръ бы чрезъ ню како себи, тако и невиномъ дедету свомъ шкодити могле. Овако принадлеже: [...] 8. Кое материцу болестну имаду (ГП - Ч 1836: 28).

болесне сисе ж <болестне сисе> Налази се и тако несрећны матера, кое макаръ да можностъ доеня притяжаваю, опеть дужность ову извршавати несмеду; еръ бы чрезъ ню како себи, тако и невиномъ дедету свомъ шкодити могле. Овако принадлеже: [...] 3. Кое болестне сисе, као краставе, раняве, чворновите и проч: имаду (ГП - Ч 1836 : 28).

болесне тајне части $ж$ <болестне тайне части $>$ - Но съ овимъ задовольити се нетреба, но за увъритисе о здравлю нЊном, валя іой цело тъло, отъ главе до ногу визитирати и добро прогледати, да неима гдигодъ какве красте, да іой коса ніе сльпльна, да іой нетеку носъ или уши, да ніе ункава, да неима у усты, носу ил' у грлу пришть, да некашль, да іой неудараю уста, ил' ноге, да іой нису сисе ил' тайне части болестне, да неима бело пранъ, раняве ил' отечене ноге, ил' руке, внутреню какву болестъ и проч (31)

БУВА ж <бува*> обично мн. мали инсект без крила (lat. Pulex) из реда Aphaniptera, дугих ногу порешених за скакане и са усним прибором подешеним за бодење и сисање, који живи као паразит на човеку $и$ топлокрвним животињама, хранећи се ғиховом крвљу. - Много пута дете плаче што е здраво стегнуто, што на нечистой постельицы лежати мора, што му тьло зло положеніе има, што га скупльни у утробы ветровы муче, што га стенице, ил' буве колю и т.д. ако се дакле у овымъ обстоятелствама стегнуте свезе попусте, ако се дете изъ нечистогъ одъла у чисто преобуче, ако се отъ ветрова чрезъ тренъ трбуа съ врућим фланеломъ, илити пакъ чрезъ еданъ клистірь опрости, акосе оть бува ил' стеница отреби, ако му се тълу добро положеніе даде; то се оно на ново безъ свакогъ ела утиша и сладко заспи (ГП Ч 1836: 18).

\section{B}

ВЕНЕРИЈА $ж<$ венерія*> lat. syphilis (Батут) заразна венерична болест. - 
Налази се и тако несрећны матера, кое макаръ да можностъ доеня притяжаваю, опетъ дужность ову извршавати несмеду; еръ бы чрезъ ню како себи, тако и невиномъ дедету свомъ шкодити могле. Овамо принадлеже: [...] 7. Кое прильпчиве болести, венерію, шугу, и проче друге имаду (ГП - Ч 1836: 28).

ВЕТРОВИ У УТРОБИ м мн. <ветрови у утробы*> гасови који се развијају $у$ иревима, стомаку. - Боль кодъ мале деце понайвыше произходи оть скупльны у утробы ветрова (ГП - Ч 1836: 73)

\section{$\Gamma$}

$\begin{array}{llll}\text { ГЛАВЕ ГАД } & \text { м } & <\text { главе } & \text { гадъ> } \\ \text { прлавштина на } & \text { кожи } & \text { глави }\end{array}$ новорођенчета. - Ако се съ главе гадъ, кои се отъ испаренія главе съ праомъ соединъног рађа, дуго време неопере, то онъ како годъ кора каква целу главу покрые: млечна кора (ГП - Ч 1836: 88).

ГЛУПОСТ ж <глупость> $>$ мна ограниченост. - Што се тиче яки пића, као ракіе, вина, пива, рума, ликера, розоліе, каффе и проч. отъ ныи како годъ отъ отрова децу чувати валя, еръ она душевне силе слабе, растень препятствую, глупость, шлогъ, различны части запаленіе, гуке, суву болестъ, напрасну смртъ, и многа друга зла узрокую (ГП - Ч 1836: 57).

ГНОЈ м < гной*> жућкастозеленкаста густа течност која настаје у ткиву човечијег или животиьског организма услед запаљења, а садржи делове распаднутог ткива, леукоциите $и$ бактерије. - Ело найпре у уста у зети, изжватати, и ньи съ плювачкомъ, а може быти и съ смрдльивымъ гноемъ уваляти, естъ еданъ отъ найгадніи, и за дете найубиточніи обычая (ГП - Ч 1836: 48).

ГРБА ж <грба*> деформација кичме $y$ виду избочине на леђима, као последица болести кичме. - Ако промыслимо: 1-0 да силне оне болести, с' коима се невина мала дечица онако горко борити мораю. 2-0 Да безчислене оне тьла мане, као: грбе, криве ноге, руке, вратъ, и т.д. кое неизброиме дечице стасъ онако грозно нарушаваю. 3-е да найпосле и саме оне силне напрасне смерти, кое выше нег' половину новорођены изъ обятія нъжны родителя онако свирњпо отргаваю, ако велимъ сва ова промыслимо, то ћемо лако увидити, да начиъ децу неговати отъ свакогъ и у свакомъ смотренію едно отъ найвећи вниманія заслужуе (ГП - Ч 1836: предговор)

ГРБАВО ТЕЛО с <грбаво тъло*> тело које има деформачију кичме у виду избочине на леђима, као последица болести кичме или старачких промена у кичми; погурено, погрбљено, гураво тело. - Рђава е раана такођеръ узрокъ, да се силна деца съ худым укоченымъ и грбавымъ тьломъ по земльи вући мораю; кою бы поредъ пристойне раане на дику и радостъ родителя, па обрану отечества красно израстила была (ГП Ч 1836: 10).

ГРИЖА ж <грижа*> 1. lat. enteralgia, 2. lat. dyspepsia neonatorum (Батут). дизентерија, оштар бол у трбуху праћен осећајем печења, гризења. - 
Такођеръ некъ недопусти неискуснымъ бабицама новорођеному коекакве цревопролителне сокове у грло сипати; еръ ови лако грчеве, грижу, запаленіе желудца, црева, опасно повраћивань, цревопролитіе и друга зла узроковати могу; а нису нуждны: еръ, као што реко, перво млеко найболь детета желудацъ чисти (ГП - Ч 1836: 17).

ГРЧ $<$ грчъ *> lat. spasmus (Батут) нагло $u$ болно стезање желуца. - [...] Оно сирьчъ много пута туђе млеко отнюдъ сносити неможе, како га у стомахъ узме, одма грчеве добіе, и повратити га мора (ГП - Ч 1836: 16).

ГУКА ж <гука*> израслина на грлу која настаје растом штитне жлезде. Тврда и врло густа ела узрокую грижу, цревопролитіе, наклоность къ гукама (шкрофулама), добрацу (rhachitis), сувой болести, много пута и саму напрасну смрть (ГП - Ч 1836: 51).

Д

ДОБРАЩ м <добрацъ*> lat. rachitis дечија болест која се испољава у деформаџији костију и зглобова, услед недостатка витамина $\mathrm{D}^{1}$. - Тврда и врло густа ела узрокую грижу,

1 У Батутовој Грађи за медицинску терминологију и у Етимологијском речнику Петра Скока појављује се следеће значење које је различито од значења датог у оригиналној потврди у загради: lat. morbilli, фрус (Батут); чибуљииа у деце по лииу (Скок); оспище, мале богиње. цревопролитіе, наклоностъ къ гукама (шкрофулама), добрацу (rhachitis), сувой болести, много пута и саму напрасну смртъ (ГП - Ч 1836: 51).

\section{Ж}

ЖУљ м <жуль*> lat. clavus (Батут). задебљало место на кожи дланова, табана и др. настало услед притиска. Ципелице некъ небуду уске, кратке, еръ ове растень прстію препятствую, жульве и проч: узрокую (ГП - Ч 1836 : 65).

\section{3}

ЗАГНОЈЕНИЈЕ $\mathrm{c}<$ >агноеніе> оно што је загнојено. - Ако бы се дакле видило, да се гадъ овай на главы купити начинъ, и да чрезъ купань у чистой воды неће да сиђе, то га са сапуномъ спрати валя, еръ изображена већъ кора сврабежъ, боль, запаленіе коже на главы, загноеніе, красте и друга зла узрокуе, препятствуе испареніе главе, растенђ косе и проч (ГП-Ч 1836: 88).

ЗАГНОЈИТИ СЕ сврш. <загноити се> почети лучити гној, напунити се гнојем (о ранама и сл.). - Ноге и друге оближе части, после сваке столице съ мокримъ сунђеромъ добро отрти валя, еръ другоячіе се лако запалити, загноити и разранявити могу (ГП - Ч 1836: 90).

ЗАГРЦНУТИ СЕ сврш. <загрцнути се*> изгубити дах, моћ гутана $и$ говора, добити грч у грлу. - Што се положенія детета при сисаню тиче, оно на крило скору хоризонтално валя да буде; да се пакъ много млека на 
еданпуть у уста спустило, и дете загрцнуло небы, нужно е, да Мати брадавицу выше уста детета држи и помало претискуе (ГП - Ч 1836: 21).

ЗАГУШЕНА КРВ ж <загушена крвъ*> крв која је густа, згрудвана, згуснута, згрушана. - Болъ кодъ мале деце понайвыше произходи оть скупльны у утробы ветрова, отъ загушене у каковой тъла части крви, и отъ скупльногъ у белой джигерицы шлайма, пакъ шта узроке ове лакше него дречанъ удалити може (ГП - Ч 1836: 73).

ЗАПАЛЕНИЈЕ с <запаленіе> реакиија организма на разна итетна дејства која се манифестује повишенем температуре, отоком, ирвенилом и сл.; запаљене.

Изр. запаленије беле џигерице с <запаленіе беле джигерице> запаљење плућа. - Но ово іошть ніе све, но скупльно у сисама млеко лако се по тьлу разударити, и найблагородніи тьла части као: мозга, беле и црне джигерице, слезыне, и т.д. запаленіе узроковати може, отъ кои несрећне ове или напрасно умру, или тако ослабе, да цео будущій животъ ни зашто друго, но за правый гробъ сматрати мораю (ГП - Ч 1836: 13).

запаленије коже на глави с <запаленіе коже на главы> - Ако бы се дакле видило, да се гадъ овай на главы купити начинъ, и да чрезъ купанъ у чистой воды неће да сиђе, то га са сапуномъ спрати валя, еръ изображена већъ кора сврабежъ, боль, запаленіе коже на главы, загноеніе, красте и друга зла узрокуе, препятствуе испареніе главе, растенъ косе и проч (ГП - Ч 1836: 88).

запаленије материце с <запаленіе материце > - Горко се вараю оне, кое мысле да доенъ здравль и лепоту матере нарушава; шта выше, жалостни примьри иляадама сведоче, да башъ оне, кое свету дужностъ ову пренебрегаваю, найгадніимъ и найопасніимъ болестима подложне есу, лютый боль, жестоко запаленіе, ране, чворови, ракъ сиса; запаленіе, отврдненіе, ракъ материце; бело пранъ, гадне красте, ране и проч (ГП - Ч 1836: 13).

запаленије мозга с <запаленіе мозга> Особито некъ се клоне, операціе, кое къ нъима непринадлеже, извршавати, као: претискати отечену главу, рђшити заращенъ езыкъ и т.д. Еръ перво лако жестоко запаленіе мозга, друго пакъ гадне уста ране узроковати може (ГП ч 1836: 7).

запаленије очију с <запаленіе очію> Едно јоштъ овде напоменути морамъ, сирьчъ: да добро пазити валя да не бы дете како одма после рођая, тако и касніе, озебло, ил' великой светлости подложено было; еръ перво поредъ силни други зла, често и саму напрасну смертъ; второ пакъ жестоко запаленіе очію узрокуе (ГП - Ч 1836: 9).

запаленије сиса с <запаленіе сиса> Горко се вараю оне, кое мысле да доень здравль и лепоту матере нарушава; шта выше, жалостни примьри иляадама сведоче, да башъ оне, кое свету 
дужность ову пренебрегаваю, найгадніимъ и найопасніимъ болестима подложне есу, лютый болъ, жестоко запаленіе, ране, чворови, ракъ сиса; запаленіе, отврдненіе, ракъ материце; бело пранъ, гадне красте, ране и проч (ГП - Ч 1836: 13).

запаленије слезине с <запаленіе слезыне > - Но ово іошть ніе све, но скупльно у сисама млеко лако се по тълу разударити, и найблагородніи тьла части као: мозга, беле и црне джигерице, слезыне, и т.д. запаленіе узроковати може, оть кои несрећне ове или напрасно умру, или тако ослабе, да цео будущій животъ ни зашто друго, но за правый гробъ сматрати мораю (ГП - Ч 1836: 13).

запаленије стомаха с <запаленіе стомаха $>$ - За много воде греяти неморати, многе матере место купаня праанъ деце употребляваю; обаче ово ни близу она добра свойства непритяжава, коя купаня, чрезъ ньга дете лако озебсти и запаленіе мозга, беле и црне джигерице, стомаха и проч: на себе навући може (ГП - Ч 1836: 87).

запаленије желуца с <запаленіе желудца > - Такођеръ некъ недопусти неискуснымъ бабицама новорођеному коекакве цревопролителне сокове у грло сипати; ерь ови лако грчеве, грижу, запаленіе желудца, црева, опасно повраћиванъ, цревопролитіе и друга зла узроковати могу; а нису нуждны: еръ, као што реко, перво млеко найболь детета желудацъ чисти (ГП - Ч 1836 : 17). запаленије црева с <запаленіе црева> Такођеръ некъ недопусти неискуснымъ бабицама новорођеному коекакве цревопролителне сокове у грло сипати; еръ ови лако грчеве, грижу, запаленіе желудца, црева, опасно повраћиванъ, цревопролитіе и друга зла узроковати могу; а нису нуждны: еръ, као што реко, перво млеко найболь детета желудацъ чисти. (ГП - Ч 1836: 17).

запаленије црне џигерице с <запаленіе црне джигерице $>$ - Но ово іошть ніе све, но скупльно у сисама млеко лако се по тьлу разударити, и найблагородніи тъла части као: мозга, беле и црне джигерице, слезыне, и т.д. запаленіе узроковати може, отъ кои несрећне ове или напрасно умру, или тако ослабе, да цео будущій животъ ни зашто друго, но за правый гробъ сматрати мораю (ГП Ч 1836: 13).

ЗАПАЛИТИ СЕ сврш. <запалити се> добити упалу, запаљење. - Ноге и друге оближе части, после сваке столице съ мокримъ сунђеромъ добро отрти валя, еръ другоячіе се лако запалити, загноити и разранявити могу (ГП - Ч 1836: 90).

ЗАРАШТЕН ЈЕЗИК м <зараштенъ, заращенъ езыкъ> lat. ankyloglossia урастао, прирастао, везан језик (?) Особито некъ се клоне, операціе, кое къ нъима непринадлеже, извршавати, као: претискати отечену главу, ръшити заращенъ езыкъ и т.д. Еръ перво лако жестоко запаленіе мозга, друго пакъ гадне уста ране узроковати може. Отокъ главе отъ саме природе спада, особито ако се тихо кои путъ на данъ 
Александра Табак

прочеше; зараштенъ пак езыкъ разрьшити не бабице, но лекара дужностъ естъ (ГП-Ч 1836: 7).

ЗЛО РАЗВЕЈЕНЕ СИСЕ Ж МН. < ЗЛО развеене сисе > неразвијене груди. Неможе мати свету доеня дужность извершавати у сльдуюћимъ случаевима: 1. Ако умре. 2. Ако су іой сисе зло развеене, ако су іой брадавице тако мале, велике ил' дубоко ураштене, да дете нипошто сисати не може (ГП - Ч 1836: 27).

3НОЈ м <зной> течност коју луче знојне жлезде кроз поре на кожи; знојење. - Избегавати валя много перь, еръ ово велику врућину, немирно спаванъ, ружне сне, зной, слабость и проч: узрокуе (ГП - Ч 1836: 67).

ЗНОЈАВАН, -вна, -вно <знояванъ*> који је ознојен, коме је избио или кога је облио зној. - Ништа маня и праанђ свогъ места имаде, после сваке сирђчъ столице, укальне детета части добро опрати валя; но да се и овомъ приликомъ чрезъ озеба шкода каква детету принела не бы, пазити валя да се опране части отма добро осуше, да вода не буде врло ладна, да се знояавно дете напрасно неопере (ГП - Ч 1836: 87).

ЗУЈАЊЕ УШИЈУ с <зуянњ ушію> $y$ ушима имати осећај иума, брујања, одзвањања. - Но и овде има изяатія; ако е сиръчъ Мати, или дойкиня врло слаба, иль мало млека имаде, дете напротивъ яко и при добромъ апетиту, ако оне при доеню болъ прсию сувость уста и грла, зуянъ ушію осећаю; а дете поредъ овы безъ свакогъ узрока неспокойно спавати, бледити, мршавити почне, то е, макаръ се првогъ живота месеца збыло, знакъ да дете са самомъ сисомъ задовольно ніе, зато му поредъ ове и друга ела давати почети валя (ГП - Ч 1836: 51).

\section{И}

ИЗОБРАЖЕНА КОРА кора> теменача, краста жућкастог изгледа на глави кора. - Ако бы се дакле видило, да се гадъ овай на главы купити начинъ, и да чрезъ купанђ у чистой воды неће да сиђе, то га са сапуномъ спрати валя, еръ изображена већъ кора сврабежъ, боль, запаленіе коже на главы, загноеніе, красте и друга зла узрокуе, препятствуе испареніе главе, растень косе и проч (ГП - Ч 1836: 88).

\section{$\mathbf{K}$}

КАШАљ м <кашаль> lat. tussis (Батут). нагло избацивање ваздуха из плућа на уста због надражаја слузокоже грла. Овако дете стомахь обтеретити неће, а матиће избегнути многа коекаква зла, као: болъ прсію, протисли, сувостъ уста, кашаль и проч. коя бы ю, кадъ ова наблюдавала небы, врло лако мучити могла (ГП - Ч 1836: 21).

КАШљАТИ несврш. <кашляти*> нагло избацивати ваздух из плућа на уста због надражаја слузокоже грла. - Но сь овимъ задовольити се нетреба, но за увњритисе о здравлю нЊном, валя іой цело тъло, отъ главе до ногу визитирати и добро прогледати, да неима гдигодъ какве красте, да іой коса ніе сльпльна, да іой нетеку носъ или уши, да ніе 
ункава, да неима у усты, носу ил' у грлу приштъ, да некашль, да іой неудараю уста, ил' ноге, да іой нису сисе ил' тайне части болестне, да неима бело прань, раняве ил' отечене ноге, ил' руке, внутреню какву болесть и проч (ГП - Ч 1836: 31$)$.

КВАРИТИ несврш. <кварити> деловати неповољно, штетно на квалитет, стање, здравље нечега, икодити (нечему).

Изр. кварити зубе <кварити зубе*> Найпосле кваре и саме зубе, ако се и онда іоштъ, кадъ ови избіяти већъ почну, употребляваю (ГП - Ч 1836: 49).

кварити прса <кварити прса*> - Деца се яко усиляваю, ноге имъ се, немогући цело тело држати, криве, тако исто и кичменица, речена орудія кваре прси, наклоность къ грудным болестима узрокую и т.д. (ГП - Ч 1836: 75).

КРАСТА $ж<$ краста*> lat. crusta (Батут). кора, скарама од сасушене крви, лимфе и гноја која се ствара на месту повреде или инфекције. - Горко се вараю оне, кое мысле да доенъ здравль и лепоту матере нарушава; шта выше, жалостни примьри иляадама сведоче, да башъ оне, кое свету дужность ову пренебрегаваю, найгадніимъ и найопасніимъ болестима подложне есу, лютый боль, жестоко запаленіе, ране, чворови, ракъ сиса; запаленіе, отврдненіе, ракъ материце; бело пранъ, гадне красте, ране и проч: ову су за оне, кое безъ свакогъ довольногъ узрока свету деня дужностъ пренебрегаваю, оть правдолюбиве природе опредълене награде; гди на противъ оне, кое природнымъ законима задоста чине и плодъ свой съ собственомъ сисом дое, одъ речены, заиста гадны и опасны болести, врло редко што знаду (ГП - Ч 1836: 13).

КРАСТАВ, -ва, -во <краставъ> онај који има красте.

Изр. крастав нос м <краставъ носъ> -

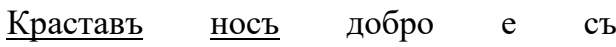
вышереченымъ отъ белогъ слеза теіомъ прати (ГП - Ч 1836: 90).

краставе сисе ж мн. <краставе сисе> Налази се и тако несрећны матера, кое макаръ да можностъ доеня притяжаваю, опеть дужность ову извршавати несмеду; еръ бы чрезъ ню како себи, тако и невиномъ дедету свомъ шкодити могле. Овако принадлеже: 1. Отвећъ младе и старе. 2. Кое врло слабъ тьла составъ имаду; кое отъ грчева много страдаю. 3. Кое болестне иㅡ, као краставе, раняве, чворновите и проч: имаду. 4. Кое рђаво млеко имаду. 5. Кое крвъ плюю или блюю. 6. Кое наклоностъ къ шкрофулама, хектики, великой болести и т.д. имаду; особито ако е насльдствена. 7. Кое прильпчиве болести, венерію, шугу, и проче друге имаду. 8. Кое материцу болестну имаду. 9. Кое отъ душевне какве болести страдаю (ГП - Ч 1836: 27-28).

КРВ БљУВАТИ несврш. <блювати крвъ*> искашљавати крв услед обољења плућа (обично од туберколозе). - Налази се и тако несрећны матера, кое макаръ да можность доеня притяжаваю, опетъ 
дужность ову извршавати несмеду; еръ бы чрезъ ню како себи, тако и невиномъ дедету свомъ шкодити могле. Овамо принадлеже: [...] 5. Кое крвъ плюю или блюю (ГП - Ч 1836: 28).

КРИВ, -ва, -во <кривъ*> који је изгубио свој нормалан, правилан облик, деформисан.

Изр. крива леђа <крива леђа*> - Ако за време доеня обадве сисе задоста млека имаю, то садъ едну, садъ другу детету пружати валя; еръ ако оно све еднако изъ исте сисе узсиса, лако разроко, или кривы леђа постати може (ГП - Ч 1836 : 20).

криве ноге <криве ноге> - Ако промыслимо: 1-0 да силне оне болести, c' коима се невина мала дечица онако горко борити мораю. 2-0 Да безчислене оне тьла мане, као: грбе, криве ноге, руке, врать, и т.д. кое неизброиме дечице стасъ онако грозно нарушаваю. 3-е да найпосле и саме оне силне напрасне смерти, кое выше нег' половину новорођены изъ обятія нъжны родителя онако свирђпо отргаваю, ако велимъ сва ова промыслимо, то ћемо лако увидити, да начиъ децу неговати отъ свакогъ и у свакомъ смотренію едно отъ найвећи вниманія заслужуе (ГП - Ч 1836: предговор).

криве руке <криве руке - Ако промыслимо: 1-0 да силне оне болести, c' коима се невина мала дечица онако горко борити мораю. 2-0 Да безчислене оне тъла мане, као: грбе, криве ноге, руке, вратъ, и т.д. кое неизброиме дечице стасъ онако грозно нарушаваю. 3-е да найпосле и саме оне силне напрасне смерти, кое выше нег' половину новорођены изъ обятія нъжны родителя онако свирђпо отргаваю, ако велимъ сва ова промыслимо, то ћемо лако увидити, да начиъ децу неговати отъ свакогъ и у свакомъ смотренію едно отъ найвећи вниманія заслужуе (ГП - Ч 1836: предговор).

криви врат <кривы врать*> - Ако промыслимо: 1-0 да силне оне болести, c' коима се невина мала дечица онако горко борити мораю. 2-0 Да безчислене оне тьла мане, као: грбе, криве ноге, руке, вратъ, и т.д. кое неизброиме дечице стасъ онако грозно нарушаваю. 3-е да найпосле и саме оне силне напрасне смерти, кое выше нег' половину новорођены изъ обятія нъжны родителя онако свирђпо отргаваю, ако велимъ сва ова промыслимо, то ћемо лако увидити, да начиъ децу неговати отъ свакогъ и у свакомъ смотренію едно отъ найвећи вниманія заслужуе (ГП - Ч 1836: предговор).

криво растење <криво растень> Сиротой дечицы боль узрокуе, слабу кожицу разчешава, пакъ много пута и криво растенђ узрокуе (ГП - Ч 1836: 65).

КРМЕљ м <крмель> громуљиия жућкасте згуснуте слузне лучевине из очију. - У очима скупльнъ крмель неваля съ поплюванимъ прстом копати; но съ поквашеномъ крпицомъ спрати га треба (ГП - Ч 1836: 89). 


\section{КРОВОПРОЛИТИЈЕ МАТЕРИЦЕ}

$<$ кровопролитіе материце> крварење материце - Одъло онда некъ промене, кадъ преко млечне грознице преиће, креветске пакъ хальице онда, кадъ кровопролитіе материце ил' са свимъ престане, ил' баремъ знаменито попусти; само у случаю, ако бы исте збогъ великогъ кровопролитія, или другогъ каквогъ узрока, врло укаляне быле, отма и после рођая променити треба (ГП - Ч 1836: 24).

\section{M}

МЛЕЧНА ГРОЗНИЦА ж $<$ мЛечна грозница*> повишење телесне температуре које настаје код жене одмах после порођаја због наглог надолажења млека. - Пре дакле, него што мати млечну грозницу добіе, довольно е, ако дете 4 найвыше 6 пута у 24 сата надоено буде, цело друго време у спаваню валя да пробавля (ГП - Ч 1836: 18).

МЛЕЧНА КОРА $ж<$ млечна кора $>$ lat. eczema seborhoicum (neonatorum) (Батут). темењача, краста жућкастог изгледа на глави. - Ако се съ главе гадъ, кои се отъ испаренія главе съ праомъ соединђног рађа, дуго време неопере, то онъ како годъ кора каква целу главу покрые: млечна кора (ГП - Ч 1836: 88).

МНОГО МОКРЕЊЕ С <МНОГО мокрень> обилно и често уринирање.Многіи тей напреже, обтерећява стомахъ, много мокренъ, а чрезъ то мршенђ узрокуе (ГП - Ч 1836: 57).
МОДРИЦА <модрица*> ж модра, тамноплава мрља на телу настала од подливене, скупљене крви (као последица удариа, јаког притиска на кожу и сл.). У првомъ случаю ће найвыше на ручицы, съ коіомъ е главу отъ якогъ ударца сачувало, или ти пакъ на стражницы едну модрицу добити, у другимъ пакъ може руку уганути, сломити и проч (ГП - Ч 1836: 77).

\section{МРТВОМ ПОДОБНО ЛЕЖАТИ} несврш. <мртавомъ подобно лежати*> бити у водоравном положају без знака живота. - Ништа мань има случаева, гди се и после овы дысанђ и кровотеченіе непочинъ, но дете безъ свакогъ живота знака мртвомъ подобно лежи, и онда нужда са собомъ доноси друга средства употребити [...] (ГП - Ч 1836: 5).

МРШАВИТИ несврш. <мршавити> постајати мршав, губити на тежини, слабити, мршати. - Но и овде има изяатія; ако е сирьчъ Мати, или дойкиня врло слаба, иль мало млека имаде, дете напротивъ яко и при добромъ апетиту, ако оне при доеню болъ прсию сувостъ уста и грла, зуянъ ушію осећаю; а дете поредъ овы безъ свакогъ узрока неспокойно спавати, бледити, мршавити почне, то е, макаръ се првогъ живота месеца збыло, знакъ да дете са самомъ сисомъ задовольно ніе, зато му поредъ ове и друга ела давати почети валя (ГП Ч 1836: 51).

МРШЕЊЕ с <мршенъ> губљење на тежини, мршављење. - Многіи тей напреже, обтерећява стомахъ, много 
мокренъ, а чрезъ то мршенђ узрокуе (ГП - Ч 1836: 57).

\section{H}

НАЗЕБ м <назебъ*> обољене горњих дисајних органа (услед неотпорности на хладноћу), прехлада. - Особито оть назеба породиля валя да се чува; зато некъ недопусти, да се врата собе нъне свакій часъ отвараю, ил' да се съ ладногъ воздуха дошавши напрасно къ нъой приближую (ГП - Ч 1836: 23).

НАПРАСНА СМРТ ж <напрасна смерть*> изненадни нагли престанак живота, животних функиија организма. - Особито некъ се Мати, да после силніе какове страсти, као: страха, гнђва, жалости, радости и т.д. такођеръ после великог движенія тьла, назеба, и проч. нафришко дете ненадои, еръ чрезъ речена се у ньой млеко тако поквари, да као отровъ на дете дъйствуе; повраћиванъ, цревопролитіе, грижу, грчеве, да и саму напрасну смерть кадкадъ преузрокуюћи (ГП - Ч 1836: 20).

\section{НАПРЕЗАТИ СТОМАК Несврш.} $<$ напрезати стомахъ*> доводити стомак y cmaње оптерећења, грчење. - Многіи тей напреже, обтерећява стомахъ, много мокрень, а чрезъ то мршенъ узрокуе (ГП - Ч 1836: 57).

\section{$\mathbf{O}$}

ОБВИЈЕНО ПУПЧИЈЕ УЖЕ ОКО BPATA c <обвіено пупчіе уже око врата> пупчана врпца која је омотана, завијена, увијена око врата. - Дысанъ и крвотеченіе есу найнужнія за животъ новорођеногъ дедета условія; зато како се дете на свђть роди, перво и перво старанъ да намъ буде, да се дысанъ и крвотеченіе у нъму започети може. Ако бы дакле узрокъ какавъ речена дъйствія препятствовао, то га што брже отъ детета удалити валя. Овымъ између многи други принадлежи 1-во обвіено пупчіе уже око врата, кое што брже одвити, или, ако то у краткости быти неможе, отсећи валя. 2-о Напунъена уста съ балама, коя фришко съ прстомъ очистити треба (ГП - Ч 1836: 5).

ОЗЕБ м <озебъ*> обољење горњих дисајних органа (услед неотпорности на хладноћу), прехлада, назеб. - Ништа манъ и праанъ свогъ места имаде, после сваке сирьчъ столице, укальне детета части добро опрати валя; но да се и овомъ приликомъ чрезъ озеба шкода каква детету принела не бы, пазити валя да се опране части отма добро осуше, да вода не буде врло ладна, да се зноявно дете напрасно неопере (ГП - Ч 1836: 87).

ОЗЕПСТИ сврш. <озебсти*> разболети се услед назеба, прехладити се, назепсти. - Едно јошть овде напоменути морамъ, сирьчъ: да добро пазити валя да не бы дете како одма после рођая, тако и касніе, озебло, ил' великой светлости подложено было; еръ перво поредъ силни други зла, често и саму напрасну смертъ; второ пакъ жестоко запаленіе очію узрокуе (ГП - Ч 1836: 9).

ОСАКАТИТИ сврш. <осакатити> учинити сакатим, убогаљити. - [...] 
оной пакъ коя луду моду детета свогъ здравлю и срећи предпочитуе, и нЊга отъ мале малоћи съ убиточнимъ орудіемъ овимъ осакатити трудисе, изъ свегъ срца желимъ, да доживи жалостно оно магновеніе, кадъ витка ћерка нъна и сама матеромъ постае, и да собственимъ очима види, како иста грозномъ мукомъ уморена, за едно съ милимъ плодомъ своимъ тавногъ гроба жертва постае (ГП - Ч 1836: 66).

ОСЛАБИТи сврш. <ослабити*> изгубити на телесној тежини, смрмати; оронути, онемоћати (услед болести). - Но ово іошть ніе све, но скупльно у сисама млеко лако се по тълу разударити, и найблагородніи тьла части као: мозга, беле и црне джигерице, слезыне, и т.д. запаленіе узроковати може, оть кои несрећне ове или напрасно умру, или тако ослабе, да цео будущій животь ни зашто друго, но за правый гробъ сматрати мораю (ГП - Ч 1836: 13).

\section{ОТВРДНЕНИЈЕ МАТЕРИЦЕ Ж}

<отврдненіе материце> ствдрюавање материце. - Горко се вараю оне, кое мысле да доень здравль и лепоту матере нарушава; шта выше, жалостни примьри иляадама сведоче, да башъ оне, кое свету дужность ову пренебрегаваю, найгадніимъ и найопасніимъ болестима подложне есу, лютый болъ, жестоко запаленіе, ране, чворови, ракъ сиса; запаленіе, отврдненіе, ракъ материце; бело прань, гадне красте, ране и проч: ову су за оне, кое безъ свакогъ довольногъ узрока свету деня дужностъ пренебрегаваю, оть правдолюбиве природе опредълене награде; гди на противъ оне, кое природнымъ законима задоста чине и плодъ свой съ собственомъ сисом дое, одъ речены, заиста гадны и опасны болести, врло редко што знаду (ГП - Ч 1836: 13).

ОТЕЧЕН, -ена, ено који је набрекнут, надувен.

Изр. отечена глава ж <отечена глава*> - Особито некъ се клоне, операціе, кое къ нъима непринадлеже, извршавати, као: претискати отечену главу, рьшити заращенъ езыкъ и т.д. Еръ перво лако жестоко запаленіе мозга, друго пакъ гадне уста ране узроковати може (ГП -Ч 1836: 7).

отечене ноге ж <отечене ноге> - Но съ овимъ задовольити се нетреба, но за увъритисе о здравлю нъном, валя іой цело тьло, отъ главе до ногу визитирати и добро прогледати, да неима гдигодъ какве красте, да іой коса ніе сльпльна, да іой нетеку носъ или уши, да ніе ункава, да неима у усты, носу ил' у грлу приштъ, да некашль, да іой неудараю уста, ил' ноге, да іой нису сисе ил' тайне части болестне, да неима бело пранъ, раняве ил' отечене ноге, ил' руке, внутреню какву болесть и проч (ГП -Ч 1836: 31).

отечене руке ж <отечене руке> - Но съ овимъ задовольити се нетреба, но за увъритисе о здравлю нЊном, валя іой цело тъло, отъ главе до ногу визитирати и добро прогледати, да неима гдигодъ какве красте, да іой коса ніе сльпльна, 
да іой нетеку носъ или уши, да ніе ункава, да неима у усты, носу ил' у грлу приштъ, да некашль, да іой неудараю уста, ил' ноге, да іой нису сисе ил' тайне части болестне, да неима бело пранъ, раняве ил' отечене ноге, ил' руке, внутреню какву болестъ и проч (ГП - Ч 1836: 31).

ОТОК м <отокъ > отечено место, отеклина.

Изр. оток главе м <отокъ главе > Особито некъ се клоне, операціе, кое къ нъима непринадлеже, извршавати, као: претискати отечену главу, рђшити заращенъ езыкъ и т.д. Еръ перво лако жестоко запаленіе мозга, друго пакъ гадне уста ране узроковати може. Отокъ главе отъ саме природе спада, особито ако се тихо кои путь на данъ прочеше; зараштенъ пак езыкъ разрьшити не бабице, но лекара дужностъ естъ (ГП - Ч 1836: 7).

I

ПљУВАТИ КРВ несврш. <плювати крвъ*> избацивати крв из уста. Налази се и тако несрећны матера, кое макаръ да можностъ доеня притяжаваю, опеть дужность ову извршавати несмеду; еръ бы чрезъ ню како себи, тако и невиномъ дедету свомъ шкодити могле. Овако принадлеже: 1. Отвећъ младе и старе. 2. Кое врло слабъ тьла составъ имаду; кое отъ грчева много страдаю. 3. Кое болестне сисе, као краставе, раняве, чворновите и проч: имаду. 4. Кое рђаво млеко имаду. 5. Кое крвъ плюю или блюю (ГП - Ч 1836: 28).
ПОВРАТИТИ сврш. <повратити> избацити кроз уста примљену храну, избљувати. - [...] оно сирђчь много пута туђе млеко отнюдъ сносити неможе, како га у стомахъ узме, одма грчеве добіе, и повратити га мора. Но ако башъ то и ніе, опеть сироте мале туђегъ млека зла сльдства необилазе: разрану имъ се уста, поквари стомахъ, добію повраћиванђ, цревопролитіе, водену болесть главе, и понайвыше, падши у суву болесть, на брзо жалостный животъ свой окончаваю (ГП - Ч 1836: 16).

ПОВРАЋИВАЊЕ с <повраћивань> избацивање садржаја желуйа кроз уста, ригање, бљување. - Такођерь некъ недопусти неискуснымъ бабицама новорођеному коекакве цревопролителне сокове у грло сипати; еръ ови лако грчеве, грижу, запаленіе желудца, црева, опасно повраћиванъ, цревопролитіе и друга зла узроковати могу; а нису нуждны: еръ, као што реко, перво млеко найболь детета желудацъ чисти (ГП - Ч 1836: 17).

ПОКВАРЕНИ ЗУБ м <поквареныи зубъ> нездрав зуб (са каријесом и сл.). Еръ много пута плювачка, особито после страсти какве, иль ако се поквареныи зубъ у усти налази, врло зла за здравль детета сльдства произвести може (ГП - Ч 1836: 48).

ПОКВАРИТИ сврш. довести у лоше, болесно, мучно, непријатно стање; оштећене. 
Изр. покварити желудац - Но ако башъ то и ніе, опетъ сироте мале туђегъ млека зла сльдства необилазе: разрану имъ се уста, поквари стомахъ, добію повраћиванъ, цревопролитіе, водену болесть главе, и понайвыше, падши у суву болесть, на брзо жалостный животь свой окончаваю (ГП - Ч 1836: 16). Ова може чрезъ преправлянь силнога млека ослабити и свакояке болести на себе навући; оно пакъ чрезъ много ело желудацъ покварити, повраћивань, цревопролитіе, грижу, и друга зла добити може (ГП - Ч 1836: 19).

покварити стомах - Но ако башъ то и ніе, опеть сироте мале туђегь млека зла сльдства необилазе: разрану имъ се уста, поквари стомахъ, добію повраћиванъ, цревопролитіе, водену болесть главе, и понайвыше, падши у суву болесть, на брзо жалостный животь свой окончаваю (ГП - Ч 1836: 16). Ова може чрезъ преправлянь силнога млека ослабити и свакояке болести на себе навући; оно пакъ чрезъ много ело желудацъ покварити, повраћивань, цревопролитіе, грижу, и друга зла добити може (ГП - Ч 1836: 19).

\section{ПОРОДИЉНА ГРОЗНИЦА ж} $<$ породильна грозница > lat. febris puerperalis (Батут) болест породиље после порођаја у виду фебрилног стања, бабиња грозница. - И сама страшна она породильна грозница, коя породиль илядама у въчность преселява, по многи славны лекара мнънію, одъ разудареног по тълу млека произылази, и понайвыше на оне, кое недою, напада; нити е мало число жена, кое су само збогъ пренебрегнутогъ доеня хектику, водену болесть , свакояке душевне болести и проч: на себе навукле (ГП - Ч 1836: 13).

ПРЕРАНИ РОЪАЈ м <прераный рођай> сувише ран, врло ран, који је пре времена порођај. - Девойчице, кое се измалена іоштъ на нъга навикну, носе га понайвыше и онда іоштъ, кадъ се већъ удаду, и трудне постану; онда пакъ управъ убиточно естъ, еръ разширеніе материце и изображеніе детета препятствуюћи прераный, или безвременый рођай узрокуе (ГП - Ч 1836: 66).

ПРИШТ м <пришть> lat. furunculus (Батут) гнојно запаљење ткива на површини коже, чир. - Но съ овимъ задовольити се нетреба, но за увъритисе о здравлю нЊном, валя іой цело тьло, отъ главе до ногу визитирати и добро прогледати, да неима гдигодъ какве красте, да іой коса ніе сльпльна, да іой нетеку носъ или уши, да ніе ункава, да неима у усты, носу ил' у грлу приштъ, да некашль, да іой неудараю уста, ил' ноге, да іой нису сисе ил' тайне части болестне, да неима бело прань, раняве ил' отечене ноге, ил' руке, внутреню какву болестъ и проч (ГП - Ч 1836: 31).

ПРОТЕРАТИ сврш. <протерати*> lat. diarea напрасно испразнити ирева у виду ретке, слузав, често крваве столице. Кадъ дано средство 3 - 4 пута дете протера, и оно стане чрезъ сисань устница, песница, иль перстића ести зактевати, то му дойкиня одма сисе дати може (ГП - Ч 1836: 34). 
ПРОТИСЛИ м мн. <протисли> веома јаки болови при којима болесник осећа као да је ударен ножем, протисии, пробади. - Овако дете стомахъ обтеретити неће, а матиће избегнути многа коекаква зла, као: болъ прсію, протисли, сувость уста, кашаль и проч. коя бы ю, кадъ ова наблюдавала небы, врло лако мучити могла (ГП - Ч 1836 : 21).

ПРСТЕ ПРИШТИНУТИ сврШ. <прсте приштинути $>$ притиснути, пригњечити прсте. - Никадъ близу врата деца некъ се неиграю, еръ чрезъ хитро отворень яко удерена быти могу, особито укланяти іи валя отъ отворены сандука, еръ се ови лако затворити, и прсте имъ приштинути могу (ГП - Ч 1836: 85).

\section{ПРСТИЋЕ РАЗДРУСКАТИ сврШ.} $<$ прстиће раздрускати> размрскати, раздробити прсте. - Већимъ децама коя већъ оду, и играчке свое отъ едногъ места на друго вуку, неваля врло тешке ствари давати, еръ се съ ныма усиляваю, и лако іи на ноге испустити, и прстиће раздрускати могу (ГП - Ч 1836: 85).

$\mathbf{P}$

РАЗБОЛЕТИ СЕ сврш. <разболети се*> бити захваћен болешћу, постати болестан. - Ако се за време доеня време кодъ матере покаже, то она свободно даль доити може; еръ збогъ нъга нити ньой, нити дедету шкода какова сльдовати може. - Затрудни л' мати за време доеня, то отма доеня нека се окане, еръ оно: 1. Зачатогъ плода изображеніе препяствуе. 2. Матерь слаби. 3. Сисаюћегъ дедета здравль, лишаваюћи га доволне ране, нарушава. Случил' се да се мати за време доеня разболе, то отма оть искусногъ лекара совъта некъ замоли, еръ само овай, добро испитавши станђ нђзино, опредълити може, валя ли и даль да дои, или велике дужности да се отрече (ГП Ч 1836: 26).

РАЗРАНИТИ УСТА сврш. <разранити уста*> добити ране на устима, повредити уста. - Но ако башъ то и ніе, опеть сироте мале туђегъ млека зла сльдства необилазе: разрану имъ се уста, поквари стомахъ, добію повраћивань, цревопролитіе, водену болесть главе, и понайвыше, падши у суву болесть, на брзо жалостный животъ свой окончаваю (ГП - Ч 1836: 16).

РАЗРОК, -ка, -ко <разрокъ*> lat. straboticus (Батут). коме је свако око управљено у другом правиу, зрикав. Ако за време доеня обадве сисе задоста млека имаю, то садъ едну, садъ другу детету пружати валя; еръ ако оно све еднако изъ исте сисе узсиса, лако разроко, или кривы леђа постати може. Особито некъ се Мати, да после силніе какове страсти, као: страха, гнђва, жалости, радости и т.д. такођеръ после великог движенія тьла, назеба, и проч. нафришко дете ненадои, еръ чрезъ речена се у ньой млеко тако поквари, да као отровъ на дете дъйствуе; повраћивань, цревопролитіе, грижу, грчеве, да и саму напрасну смертъ кадкадъ преузрокуюћи (ГП - Ч 1836: 20). 
РАК м <ракъ> lat. cancer тешка болест која обухвата разне врсте малигних тумора.

Изр. рак материце м <ракъ материце> Горко се вараю оне, кое мысле да доень здравль и лепоту матере нарушава; шта выше, жалостни примьри иляадама сведоче, да башъ оне, кое свету дужность ову пренебрегаваю, найгадніимъ и найопасніимъ болестима подложне есу, лютый боль, жестоко запаленіе, ране, чворови, ракъ сиса; запаленіе, отврдненіе, ракъ материце; бело пранъ, гадне красте, ране и проч: ову су за оне, кое безъ свакогъ довольногъ узрока свету деня дужностъ пренебрегаваю, оть правдолюбиве природе опредълене награде; гди на противъ оне, кое природнымъ законима задоста чине и плодъ свой съ собственомъ сисом дое, одъ речены, заиста гадны и опасны болести, врло редко што знаду (ГП - Ч 1836: 13).

рак сиса $\mathrm{м}<$ ракъ сиса $>-$ Горко се вараю оне, кое мысле да доенъ здравль и лепоту матере нарушава; шта выше, жалостни примьри иляадама сведоче, да башъ оне, кое свету дужность ову пренебрегаваю, найгадніимъ и найопасніимъ болестима подложне есу, лютый боль, жестоко запаленіе, ране, чворови, ракъ сиса; запаленіе, отврдненіе, ракъ материце; бело пранъ, гадне красте, ране и проч: ову су за оне, кое безъ свакогъ довольногъ узрока свету деня дужность пренебрегаваю, отъ правдолюбиве природе опредълене награде; гди на противъ оне, кое природнымъ законима задоста чине и плодъ свой съ собственомъ сисом дое, одъ речены, заиста гадны и опасны болести, врло редко што знаду (ГП - Ч 1836: 13).

PАНА ж <рана> lat. vulnus; повреда телесног ткива изазвана оштрим оруђем, опекотином, озеблином и др.

Изр. ране сиса ж <ране сиса $>-$ Горко се вараю оне, кое мысле да доенъ здравль и лепоту матере нарушава; шта выше, жалостни примьри иляадама сведоче, да башъ оне, кое свету дужность ову пренебрегаваю, найгадніимъ и найопасніимъ болестима подложне есу, лютый болъ, жестоко запаленіе, ране, чворови, ракъ сиса; запаленіе, отврдненіе, ракъ материце; бело пранъ, гадне красте, ране и проч: ову су за оне, кое безъ свакогъ довольногъ узрока свету деня дужностъ пренебрегаваю, отъ правдолюбиве природе опредълене награде; гди на противъ оне, кое природнымъ законима задоста чине и плодъ свой съ собственомъ сисом дое, одъ речены, заиста гадны и опасны болести, врло редко што знаду (ГП - Ч 1836: 13).

уста ране ж < ране уста $>$ - Особито некъ се клоне, операціе, кое къ нъима непринадлеже, извршавати, као: претискати отечену главу, рьшити заращенъ езыкъ и т.д. Еръ перво лако жестоко запаленіе мозга, друго пакъ гадне уста ране узроковати може (ГП Ч 1836: 7). 
РАҢАВ, -ва, -во који је пун рана, покривен ранама, изранављен.

Изр. рањава уста ж <ранява уста*> Но пре него што иста детету первый путъ сисе даде, нуждно е найпре да се окупа, и цело тьло, особито сисе добро опере, а после донешено млеко изцеди; еръ ако е пре какво съ ранявымъ устма дете надоила, то исту болесть и на новогъ питомца лако пренети може (ГП - Ч 1836: 34).

рањаве ноге ж <раняве ноге> - Но съ овимъ задовольити се нетреба, но за увъритисе о здравлю нъном, валя іой цело тъло, отъ главе до ногу визитирати и добро прогледати, да неима гдигодъ какве красте, да іой коса ніе сльпльна, да іой нетеку носъ или уши, да ніе ункава, да неима у усты, носу ил' у грлу приштъ, да некашль, да іой неудараю уста, ил' ноге, да іой нису сисе ил' тайне части болестне, да неима бело пранъ, раняве ил' отечене ноге, ил' руке, внутреню какву болесть и проч (ГП - Ч 1836: 31).

рањаве руке ж <раняве руке> - Но съ овимъ задовольити се нетреба, но за увъритисе о здравлю нъном, валя іой цело тьло, отъ главе до ногу визитирати и добро прогледати, да неима гдигодъ какве красте, да іой коса ніе сльпльна, да іой нетеку носъ или уши, да ніе ункава, да неима у усты, носу ил' у грлу приштъ, да некашль, да іой неудараю уста, ил' ноге, да іой нису сисе ил' тайне части болестне, да неима бело пранъ, раняве ил' отечене ноге, ил' руке, внутреню какву болестъ и проч (ГП - Ч 1836: 31).

рањаве сисе ж <раняве сисе > - Налази се и тако несрећны матера, кое макаръ да можностъ доеня притяжаваю, опетъ дужностъ ову извршавати несмеду; еръ бы чрезъ ню како себи, тако и невиномъ дедету свомъ шкодити могле. Овако принадлеже: 1. Отвећъ младе и старе. 2. Кое врло слабъ тъла составъ имаду; кое отъ грчева много страдаю. (27) 3. Кое болестне сисе, као краставе, раняве, чворновите и проч: имаду. 4. Кое рђаво млеко имаду. 5. Кое крвъ плюю или блюю. 6. Кое наклоность къ шкрофулама, хектики, великой болести и т.д. имаду; особито ако е насльдствена. 7. Кое прильпчиве болести, венерію, шугу, и проче друге имаду. 8. Кое материцу болестну имаду. 9. Кое оть душевне какве болести страдаю (ГП - Ч 1836: 28).

\section{РАШИРЕНИЈЕ МАТЕРИЦЕ С} <разширеніе материце $>$ раширене, повећање обима, проширење материце. - Девойчице, кое се измалена іошть на нъга навикну, носе га понайвыше и онда іоштъ, кадъ се већъ удаду, и трудне постану; онда пакъ управъ убиточно естъ, еръ разширеніе материце и изображеніе детета препятствуюћи прераный, или безвременый рођай узрокуе (ГП - Ч 1836: 66).

РУкУ УГАНУТИ сврш. <руку уганути> повредити руку прекомерним напињањем зглоба, истезањем зглобних тетива, искренути зглоб, ишчашити. У првомъ случаю ће найвыше на 
ручицы, съ коіомъ е главу отъ якогъ ударца сачувало, или ти пакъ на стражницы едну модрицу добити, у другимъ пакъ може руку уганути, сломити и проч (ГП - Ч 1836: 77).

\section{C}

СВРАБЕЖ м <сврабежъ> lat. pruritus (Батут) 1. осећај голицања и пецккања на кожи која подстиче на чешање; свраб. Ако бы се дакле видило, да се гадъ овай на главы купити начинђ, и да чрезъ купанъ у чистой воды неће да сиђе, то га са сапуномъ спрати валя, еръ изображена већъ кора сврабежъ, боль, запаленіе коже на главы, загноеніе, красте и друга зла узрокуе, препятствуе испареніе главе, растенъ косе и проч (ГП - Ч 1836: 88).

СЛАБ, -ба, -бо који није довољно јак, чврстог телесног састава.

Изр. слаба кичменица ж <слаба кичменица*> - Никадъ неваля дете пре 11-огъ живота месеца на ноге устаяти, стояти, илъ одити учити; еръ до овогъ времена, ноге, кичменица, и друге кости тако су слабе, да безъ великогъ вреда цело тело одржати нипошто немогу (ГП - Ч 1836: 76).

слабе кости ж <слабе кости $>-$ Никадъ неваля дете пре 11-огъ живота месеца на ноге устаяти, стояти, иль одити учити; еръ до овогъ времена, ноге, кичменица, и друге кости тако су слабе, да безъ великогъ вреда цело тело одржати нипошто немогу (ГП - Ч 1836: 76). слабе ноге ж <слабе ноге> - Никадъ неваля дете пре 11-огъ живота месеца на ноге устаяти, стояти, иль одити учити; еръ до овогъ времена, ноге, кичменица, и друге кости тако су слабе, да безъ великогъ вреда цело тело одржати нипошто немогу (ГП - Ч 1836: 76).

СЛАБОСТ ж <слабость> изнемоглост, немоћ, недостатак снаге, јачине. Избегавати валя много перћ, еръ ово велику врућину, немирно спаванъ, ружне сне, зной, слабость и проч: узрокуе (ГП - Ч 1836: 67).

СЛОМИТИ сврш. падом или ударом изазвати лом кости

Изр. сломити руку <сломити руку> - У првомъ случаю ће найвыше на ручицы, съ коіомъ е главу отъ якогъ ударца сачувало, или ти пакъ на стражницы едну модрицу добити, у другимъ пакъ може руку уганути, сломити и проч (ГП - Ч 1836: 77).

СТЕНИЦА ж <стеница> (обично мн) породица инсеката, паразита Heteroptera ca неједнаким крилима и ропием за сисањем које изазивају сварб u осип код човека. - Много пута дете плаче што е здраво стегнуто, што на нечистой постельицы лежати мора, што му е тظло зло положеніе има, што га скупльни у утробы ветровы муче, што га стенице, ил' буве колю и т.д. ако се дакле у овымъ обстоятелствама стегнуте свезе попусте, ако се дете изъ нечистогъ одъла у чисто преобуче, ако се отъ ветрова чрезъ тренъ трбуа съ врућим фланеломъ, илити пакъ чрезъ еданъ 
клистіръ опрости, акосе оть бува ил' стеница отреби, ако му се тьлу добро положеніе даде; то се оно на ново безъ свакогъ ела утиша и сладко заспи (ГП - Ч 1836: 18).

\section{СТОМАХ ОПТЕРЕТИТИ сврШ.} $<$ <бтеретити стомахъ> довести у теже стане стомак, прејести се. - Ако се, као што обично быва, време рођая дойкинъ съ истымъ матере неслаже, сирьчъ ако е она пре родила, то млеко нъно већъ неће моћи желудацъ детета очистити, зато дакле детету найпре - но чрезъ лекара - цревопролителный сокъ какавъ дати треба, еръ другачіе дете стомахъ обтеретити и разболетисе може (ГП - Ч 1836: 34).

СУВОСТ м <сувостъ> осећај недостатка влажности.

Изр. сувост грла <сувость грла> - Но и овде има изяатія; ако е сирђчь Мати, или дойкиня врло слаба, иль мало млека имаде, дете напротивъ яко и при добромъ апетиту, ако оне при доеню боль прсию сувостъ уста и грла, зуянь ушію осећаю; а дете поредъ овы безъ свакогъ узрока неспокойно спавати, бледити, мршавити почне, то е, макаръ се првогъ живота месеца збыло, знакъ да дете са самомъ сисомъ задовольно ніе, зато му поредъ ове и друга ела давати почети валя (ГП - Ч 1836: 51)

сувост уста <сувость уста> - Овако дете стомахъ обтеретити неће, а матиће избегнути многа коекаква зла, као: боль прсію, протисли, сувостъ уста, кашаль и проч. коя бы ю, кадъ ова наблюдавала небы, врло лако мучити могла (ГП - Ч 1836: 21).

$\mathbf{T}$

ТВРДА СТОЛИЦА ж <тверда столица*> lat. obstipatio. отежано пражњење организма, затвор. - Ова е особито едно ело за децу, коя су слаба, и често цревопролитіе имаду; обаче здравой децы непрія, особито оной, коя тверду столицу имаю, коіой много пута и шкодльива естъ; прави се пакъ овако: узми фришкогъ, зрелогъ отъ люске очишћеногъ жира, исецы га на мале комадиће, и изпржи у шерпеньицы као кафу, пакъ онда изтри у ситанъ пра (ГП - Ч 1836: 44).

ТЕЛА МАНЕ ж <тьла мане> телесни недостатак, деформитет, аномалија. Ако промыслимо: 1-0 да силне оне болести, с' коима се невина мала дечица онако горко борити мораю. 2-0 Да безчислене оне тьла мане, као: грбе, криве ноге, руке, вратъ, и т.д. кое неизброиме дечице стасъ онако грозно нарушаваю. 3-е да найпосле и саме оне силне напрасне смерти, кое выше нег' половину новорођены изъ обятія нъжны родителя онако свирђпо отргаваю, ако велимъ сва ова промыслимо, то ћемо лако увидити, да начинъ децу неговати отъ свакогъ и у свакомъ смотренію едно отъ найвећи вниманія заслужуе (ГП - Ч 1836: предговор).

ТЕһИ НОС с <тећи нос*> појављивање исцетка из носа, најчешће бала, слина, слузи, иурење из носа (?). - Но съ овимъ задовольити се нетреба, но за увъритисе 
о здравлю ньном, валя іой цело тьло, отъ главе до ногу визитирати и добро прогледати, да неима гдигодъ какве красте, да іой коса ніе сльпльна, да іой нетеку носъ или уши, да ніе ункава, да неима у усты, носу ил' у грлу приштъ, да некашль, да іой неудараю уста, ил' ноге, да іой нису сисе ил' тайне части болестне, да неима бело прань, раняве ил' отечене ноге, ил' руке, внутреню какву болесть и проч (ГП - Ч 1836: 31).

ТЕһИ УШИ с <тећи уши*> појављивање исиетка из уха, најчешће гнојавог, иурење из ушију (?). - Но съ овимъ задовольити се нетреба, но за увъритисе о здравлю нЊном, валя іой цело тъло, отъ главе до ногу визитирати и добро прогледати, да неима гдигодъ какве красте, да іой коса ніе сльпльна, да іой нетеку носъ или уши, да ніе ункава, да неима у усты, носу ил' у грлу пришть, да некашль, да іой неудараю уста, ил' ноге, да іой нису сисе ил' тайне части болестне, да неима бело прань, раняве ил' отечене ноге, ил' руке, внутреню какву болестъ и проч (ГП - Ч 1836: 31).

\section{$\mathbf{y}$}

УГЊАВИТИ сврш. <угнявити> угушити, задавити. - Ако су цуцле, као што се обычно праве, врло велике, то развалюю уста детета, ако ли су пак врло мале, лако у грло упасти и дете угнявити могу (ГП - Ч 1836: 49).

УДАРИТИ НОГЕ сврш. <ударити уста*> имати лош мирис ногу. - Но съ овимъ задовольити се нетреба, но за увъритисе о здравлю нЊном, валя іой цело тьло, отъ главе до ногу визитирати и добро прогледати, да неима гдигодъ какве красте, да іой коса ніе сльпльна, да іой нетеку носъ или уши, да ніе ункава, да неима у усты, носу ил' у грлу приштъ, да некашль, да іой неудараю уста, ил' ноге, да іой нису сисе ил' тайне части болестне, да неима бело пранъ, раняве ил' отечене ноге, ил' руке, внутреню какву болесть и проч (ГП - Ч 1836: 31).

УДАРИТИ УСТА сврш. <ударити уста*> имати лош мирис из уста. - Но съ овимъ задовольити се нетреба, но за увъритисе о здравлю нъном, валя іой цело тъло, отъ главе до ногу визитирати и добро прогледати, да неима гдигодъ какве красте, да іой коса ніе сльпльна, да іой нетеку носъ или уши, да ніе ункава, да неима у усты, носу ил' у грлу приштъ, да некашль, да іой неудараю уста, ил' ноге, да іой нису сисе ил' тайне части болестне, да неима бело пранъ, раняве ил' отечене ноге, ил' руке, внутреню какву болестъ и проч (ГП - Ч 1836: 31).

УМИРАњЕ с <умирань> губљење знакова живота, падање у стање гашења животних функиија живих организама. - И сама страшна она породильна грозница, коя породиль илядама у въчность преселява, по многи славны лекара мнънію, одъ разудареног по тълу млека произылази, и понайвыше на оне, кое недою, напада; нити е мало число жена, кое су само збогъ пренебрегнутогъ доеня хектику, водену 
болестъ, свакояке душевне болести и проч: на себе навукле. Ако сва добра посмотримо лако ћемо увидити. 1-о да оне матере, кое децы своіой сису отричу великомъ числу гадны и опасны болести на себе подлажу, отъ кои оне, кое чада своя саме дое, врло редко страдаю; сльдователно 2-о да и умиранђ оны матера, кое недою, много веће быти мора, неголи оны кое дужнсть ову исполняваю (ГП - Ч 1836: 13-14).

УМРЕТИ сврш. <умрети*> престати живети, преминути. - Неможе мати свету доеня дужность извершавати у сльдуюћимъ случаевима: 1. Ако умре. 2. Ако су іой сисе зло развеене, ако су іой брадавице тако мале, велике ил' дубоко ураштене, да дете нипошто сисати не може (ГП - Ч 1836: 27).

УРАШТЕНЕ БРАДАВИЦЕ Ж <ураштене брадавице> (обично мн.) урасле, увучене брадавице. - Неможе мати свету доеня дужность извершавати у сльдуюћимъ случаевима: 1. Ако умре. 2. Ако су іой сисе зло развеене, ако су іой брадавице тако мале, велике ил' дубоко ураштене, да дете нипошто сисати не може (ГП - Ч 1836: 27).

\section{УСТА РАЗРАњАВИТИ сврШ.} <разранявити уста > учинити уста рањавим, повредити на више места. Пре него што дете сисати почне, добро е брадавицу съ млекомъ мало поквасити; а после свакогъ доеня валя уста детета съ мокромъ крпицомъ обвіенымъ прстомъ добро отрти, еръ заоставше у ныма млеко лако ускиснути и уста разранявити може (ГП - Ч 1836: 19).
$\Phi$

ФРАС м <фрасъ> грч који настаје из страха (нарочито код мале деце) $)^{2}$. Пазити вали да се дете напрасно чрезъ какву лупу изъ сна нетргне, еръ збогъ тога многа зла, кадкадъ и самъ фрасъ добити може (ГП - Ч 1836: 70).

$\mathbf{X}$

ХЕКТИКА ж <хектика*> плућна туберколоза, сушица. -Налази се и тако несрећны матера, кое макарь да можность доеня притяжаваю, опетъ дужность ову извршавати несмеду; еръ бы чрезъ ню како себи, тако и невиномъ дедету свомъ шкодити могле. Овако принадлеже: 1. Отвећъ младе и старе. 2. Кое врло слабъ тьла составъ имаду; кое отъ грчева много страдаю. (27) 3. Кое болестне сисе, као краставе, раняве, чворновите и проч: имаду. 4. Кое рђаво млеко имаду. 5. Кое крвъ плюю или блюю. 6. Кое наклоностъ къ шкрофулама, хектики, великой болести и т.д. имаду; особито ако е насльдствена. 7. Кое прильпчиве болести, венерію, шугу, и проче друге имаду. 8. Кое материцу болестну имаду. 9. Кое отъ душевне какве болести страдаю (ГП - Ч 1836: 28).

ХУДО УКОЧЕЊЕ с <ХУдо укочень*> трајна укоченост, непокретност

\footnotetext{
${ }^{2}$ У Медиичиском речнику др А. Костића наводи се да је фрас lat. eclampsia infantum грчене тела код деце узроковано повишеном телесном температуром.
} 
појединих делова тела. -Найвеће втеченіе у животь и здравль како совершеногъ човека, тако и малогъ дедета, имаде раана. Выше него една трећа часть деце само због злочесте раане умире. Рђава е раана такођеръ узрокъ, да се силна деца съ худым укоченымъ и грбавымъ тъломъ по земльи вући мораю; кою бы поредъ пристойне раане на дику и радость родителя, па обрану отечества красно израстила была (ГП - Ч 1836: 10).

\section{Ц}

ЦРВЕН ОКОЛО ПУПКА м <црвенъ около пупка > црвенило пупка на новорођенчету. - Крпица съ коіомъ се пупакъ покрива, може се, докъ пупчіи чворъ неотпадне съ путеромъ ил' зейтиномъ мазати, а после докъ се годъ около пупка црвенъ види, съ ракіомъ (ГП - Ч 1836: 62).

ЦРЕВА СРАСТЕЊЕ с <срастенЬ црева > аномалија ирева, спајање ирева у једну иелину растући, везивање, завезиване ирева. - Кровотеченіе разширеніе прсію, и растень сиса препятствуе; стомаха дњйство нарушава; црева едногъ съ другимъ срастенђ узрокуе (ГП - Ч 1836 : 66).

\section{ЦРЕВОПРОЛИТИЈЕ}

c

<цревопролитіе> lat. diarea учестало пражнење ирева у облику ретке, слузаве, често крваве столице. - Ова е особито едно ело за децу, коя су слаба, и често цревопролитіе имаду; обаче здравой децы непрія, особито оной, коя тверду столицу имаю, коіой много пута и шкодльива естъ; прави се пакъ овако: узми фришкогъ, зрелогъ отъ люске очишћеногъ жира, исецы га на мале комадиће, и изпржи у шерпеньицы као кафу, пакъ онда изтри у ситанъ пра (ГП - Ч 1836: 44).

ЦРНКАСТА КОРИЦА с <црнкаста корица> помало ирна, тврда корица од секрета, слузи, слина у носу (?). - Зато ако се опази, да е носъ нечистъ, да се у нъму отъ осушены бала црнкаста корица каква ватати почне, то ю найпре съ неосольномъ масћу намазати, и тако отмекшати, а после съ прстомъ изчистити валя (ГП - Ч 1836: 90).

\section{$\mathbf{Y}$}

ЧВОРНОВИТЕ СИСЕ ж <чворновите сисе> квргасте дојке, пуне квржица, чворова. - Налази се и тако несрећны матера, кое макаръ да можность доеня притяжаваю, опеть дужность ову извршавати несмеду; еръ бы чрезъ ню како себи, тако и невиномъ дедету свомъ шкодити могле. Овако принадлеже: 1. Отвећъ младе и старе. 2. Кое врло слабъ тьла составъ имаду; кое отъ грчева много страдаю. (27) 3. Кое болестне сисе, као краставе, раняве, чворновите и проч: имаду (ГП - Ч 1836 : 28).

ЧВОРОВИ СИСА ж <чворови сиса $>$ болесни израштај у организму, квржице. - Горко се вараю оне, кое мысле да доенъ здравль и лепоту матере нарушава; шта выше, жалостни примьри иляадама сведоче, да башъ оне, кое 
свету дужность ову пренебрегаваю, найгадніимъ и найопасніимъ болестима подложне есу, лютый боль, жестоко запаленіе, ране, цворови, ракъ сиса; запаленіе, отврдененіе, ракъ материце; бело пранъ, гадне красте, ране и проч (ГП - Ч 1836: 13).

Ш

ШКРОФУЛА ж <шкрофула*> израслина на грлу која настаје растом штитне жлезде. - Тврда и врло густа ела узрокую грижу, цревопролитіе, наклоность къ гукама (шкрофулама), добрацу (rhachitis), сувой болести, много пута и саму напрасну смрть (ГП - Ч 1836: 51).

ШЛАЈМ м <шлаймъ*> слузав испљувак, слуз. - Болъ кодъ мале деце понайвыше произходи оть скупльны у утробы ветрова, отъ загушене у каковой тظла части крви, и оть скупльногъ у белой джигерицы шлайма, пакъ шта узроке ове лакше него дречань удалити може (ГП Ч 1836: 73).

ШУГА ж <шуга*> заразна кожна болест праћена великим сврабом, коју изазива паразит шугараи. - Налази се и тако несрећны матера, кое макаръ да можностъ доеня притяжаваю, опетъ дужностъ ову извршавати несмеду; еръ бы чрезъ ню како себи, тако и невиномъ дедету свомъ шкодити могле. Овако принадлеже: 1. Отвећъ младе и старе. 2. Кое врло слабъ тьла составъ имаду; кое отъ грчева много страдаю. 3. Кое болестне сисе, као краставе, раняве, чворновите и проч: имаду. 4. Кое рђаво млеко имаду. 5. Кое крвъ плюю или блюю. 6. Кое наклоность къ шкрофулама, хектики, великой болести и т.д. имаду; особито ако е насльдствена. 7. Кое прильпчиве болести, венерію, шугу, и проче друге имаду. 8. Кое материцу болестну имаду. 9. Кое оть душевне какве болести страдаю (ГП - Ч 1836: 28).

\section{5. Закључак}

У делу Чадољуб или неговање деце у првим живота годинама Гаврила Пекаровића (1836) забележене су 163 терминолошке јединице, од чега су 54 изрази. Након поређења са савременим медицинским речницима (Вишејезички медицински речник и Медицински лексикон), можемо закључити да је медицинска терминологија прилично измењена јер савремену медицинску терминологију чине углавном интернационализми (Rječnik hrvatskoga ili srpkog jezika JAZU I-XXIII 1880-1976; Вујаклија 1961; Клајн и Шипка 2006). Развијен терминолошки систем домаћих назива у анализираном делу сведочи о преданом раду Гаврила Пекаровића, зачетника српске педијатрије. На крају би се могло поставити питање због чега је процес формирања терминологије текао у смеру усвајања туђих термина (в. 
Катић 1982). Једини оправдан одговор на ово питање био би развој науке и губљење пуризма, који отварају врата ка најједноставнијем моделу за богаћење лексикона - позајмљивању, а како се развија наука тако се и терминолошки систем шири, те се самим тим створила и тежња ка усвајању заједничке медицинске интернационалне терминологије, која би омогућила бржу размену информација и успешнију комуникацију (Бјелаковић 2004: 32). Ова грађа свакако пружа низ могућности за даља истраживања, а једно од њих би могло бити - Зашто човек у свакодневној комуникацији каже да има упалу плућа, а не пнеумонију?

\section{И З В О Р И}

Пекаровић, Гаврил (1836). Чадољуб или неговање деце у првим живота годинама. Будим.

\section{ЛИ Т Е Р А Т У Р А}

Бјелаковић, Исидора (2004). Називи за болести у лекарушама са територије Војводине у 19. веку. Прилози проучаваюу језика. Нови Сад. 34.

Бјелаковић, Исидора Г. (2013). Предлог микроструктуре речника славеносрпског језика. Зборник Матице српске за књижевност и језик. 61/3: 803-809.

Бјелаковић, Исидора и Цветковић-Теофиловић, Ирена (2017). Макроструктура и микроструктура Речника славеносрпског језика (огледна свеска). Речник славеносрпског језика. Огледна свеска (ур. И. Бјелаковић, И. ЦветковићТеофиловић, А. Милановић). Нови Сад: Матица српска. 17-32.

Бјелаковић, И. (2017). Терминологија код Срба у 18. и 19. веку (математичка географија и картографија).

〈http://www.dvapera.rs/resursi/Isidora-Bjelakovic-Terminologija-kod-Srba.pdf>

Вујаклија, Милан (1961). Лексикон страних речи и израза. Београд: Просвета.

Гортан-Премк, Даринка (1988). О месту термина у лексичком фонду. У: Научни састанак слависта у Вукове дане. Терминологија- теорија и пракса, 18/1. Београд. 15-21.

Драгићевић, Рајна (2007). Лексикологија српског језика. Београд: Завод за уџбенике. Јовановић, Батут, Милан (1887). Грађа за медицинску терминологију. Нови Сад.

Кашић, Јован (1984). Извори и грађа за речник славеносрпског језика. У: Лексикографија и лексикологија. Зборник радова. Нови Сад: Матица српска. 91-95.

Клајн, Иван и Милан Шипка (2006). Велики речник страних речи и израза. Нови Сад: Прометеј.

Костић, Александар (1987). Вишејезички медииински речник. Београд: Нолит. 
Медищински лексикон (1983). I-II. Београд: Вук Караџић-Larousse.

Младеновић, Александар (1979). Напомене о транскрипцији и критичком издавању старих српских текстова из XVIII и XIX века. Зборник за филологију $u$ лингвистику. Нови Сад. ХХІІ/2: 95-129

Павловић, Будимир Д. и Милорад Велисављев (1995). Сећање на првог писца прве српске и југословенске педијатријске књиге о деци. У: Зборник радова Научног скупа Природне и математичке науке у Срба у 18. и првој половини 19. века. Нови Сад: Српска академија наука и уметности, ОгранакУниверзитет - Матица српска. 155-159.

РСАНУ: Речник српскохрватског книжевног и народног језика, I-XIV. Београд: Институт за српски језик САНУ, 1959- .

PMC: Речник српскохрватског књижевног језика, I-VI. Нови Сад - Загреб: Матица српска - Матица хрватска, 1969.

Станојевић, Владимир (1953). Историја медицине. Београд - Загреб: Медицинско издавачко предузеће „Медицинска књига”.

Токин, Милан (1953). Стеријин пријатељ др Гаврило Пекаровић: прилог историји медицине у Војводини. Рад војвођанских музеја. Бр. 2. Нови Сад: Војвођански музеј. 161-170.

700 година медищине у Срба (1971). Београд: Галерија Српске академије наука и уметности.

Macanović, Ana (2018). Srpska jezikoslovna terminologija u 19. veku. Beograd: Institut za srpski jezik.

RJAZU: Rječnik hrvatskoga ili srpkog jezika. JAZU I-XXIII. Zagreb, 1880-1976.

Skok, Petar (1971-1974). Etimologijski rječnik hrvatskoga ili srpskoga jezika, 1-4. Zagreb.

Šipka, Danko (1998). Osnovi leksikologije i srodnih disciplina. Novi Sad: Matica srpska. 
Aleksandra Tabak

THE LEXICOGRAPHIC TREATMENT OF TERMINOLOGY FOR DISEASES, SYMPTOMS AND SIGNS IN OPUS "ČADOLJUB ILI NEGOVANJE DECE U PRVIM ŽIVOTA GODINAMA" BY GAVRIL PEKAROVIĆ (1836)

\section{SUMMARY}

This paper represents dictionary of terminology for diseases, symptoms and signs noted in opus "Čadoljub ili negovanje dece u prvim života godinama" written by Gavril Pekarović in 1836. Besides dictionary, the thesis gives basic information about medicine as science discipline in Serbian history and the data are compared with contemporary medical dictionaries "Višejezički medicinski rečnik" and "Medicinski leksikon".

KEYWORDS: terminology for diseases, symptoms, signs, terminology, medicine, 19 th century.

Мср Александра Табак

Одсек за српски језик и лингвистику Филозофски факултет, Универзитет у Новом Саду Србија anjatabak5@gmail.com 
